\title{
FÉMHABOK STRUKTÚRÁJÁNAK ELEMZÉSE ÉS MODELLEZÉSE
}

\section{STRUCTURAL ANALYSIS AND MODELLING OF METAL FOAMS}

\author{
Varga Tamás Antal ${ }^{1}$, Mankovits Tamás ${ }^{2}$, Kocsis Imre $^{3}$, Budai István ${ }^{4}$, \\ Balogh Gábor ${ }^{5}$, Gábora András $^{6}$, Kozma István $^{7}$, Manó Sándor ${ }^{8}$ \\ ${ }^{I}$ Debreceni Egyetem, Müszaki Kar, Gépészmérnöki Tanszék; 4028, Magyarország, \\ Debrecen, Ótemetö utca, 2-4; Telefon: +36202268703; tomivarga27@gmail.com \\ ${ }^{2}$ Debreceni Egyetem, Müszaki Kar, Gépészmérnöki Tanszék; 4028, Magyarország, \\ Debrecen, Ótemetö utca, 2-4; Telefon: +36-52-415-155/77780; \\ tamas.mankovits@eng.unideb.hu \\ ${ }^{3}$ Debreceni Egyetem, Müszaki Kar, Müszaki Alaptárgyi Tanszék; 4028, Magyaror- \\ szág, Debrecen, Ótemetö utca, 2-4; Telefon: +36-52-415-155/77732; \\ kocsisi@eng.unideb.hu
}

${ }^{4}$ Debreceni Egyetem, Müszaki Kar, Müszaki Menedzsment és Vállalkozási Tanszék; 4028, Magyarország, Debrecen, Ótemetö utca, 2-4; Telefon: +36-52-415155/77754; budai.istvan@eng.unideb.hu

${ }^{5}$ Debreceni Egyetem, Müszaki Kar, Gépészmérnöki Tanszék; 4028, Magyarország, Debrecen, Ótemetö utca, 2-4; Telefon: +36-52-415-155/77778; balogh.gabor@eng.unideb.hu

${ }^{6}$ Debreceni Egyetem, Müszaki Kar, Gépészmérnöki Tanszék; 4028, Magyarország, Debrecen, Ótemetö utca, 2-4; Telefon: +36-52-415-155/77704; andrasgabora@eng.unideb.hu

${ }^{7}$ Széchenyi István Egyetem, Müszaki Tudományi Kar, Anyagtudományi és Technológiai Tanszék; 9026, Magyarország, Györ, Egyetem tér 1; Telefon: +36-96-503400/3582; kozma@sze.hu

${ }^{8}$ Debreceni Egyetem, Ortopédiai Klinika; 4028, Magyarország, Debrecen, Nagyerdei körút 98; Telefon: +36-52-411-717/56983; manos@med.unideb.hu

\begin{abstract}
The development of an efficient procedure for 3D modelling and finite element simulation of metal foams is one of the greatest challenges to engineer researchers nowadays. Creating 3D CAD model is alone a demanding engineering task due to its extremely complex geometry, and the proper finite element analysis process is still in the center of the research. Quantitative image analysis has also been done which gives detailed information about the structure of the metal foam. The volume ratios were derived by area fraction and line analysis as well. The two applied methods were compared. The main goal of this part of the project is to obtain structural information and to determine the homogeneity or the in-homogeneity property of the metal foam specimens taken from different locations.
\end{abstract}

Keywords: metal foam, area fraction analysis, line analysis, line analysis, statistical evaluation, modelling. 


\section{Összefoglalás}

Napjaink mérnöki kutatásainak egyik nagy kihívása egy hatékony 3D modellező eljárás és végeselem szimuláció kifejlesztése a fémhabokra vonatkozóan. Egy 3D CAD modell létrehozása már önmagában is komoly mérnöki feladat, különösen a fémhab összetett geometriája miatt. Ezek működöképes végeselem szimulációja még mindig a kutatások középpontjában áll. Kutatásunk során kvantitatív képelemzést végeztünk, amely részletes információt ad a fémhab szerkezetéröl. A térfogatarányokat területelemzéssel és vonalelemzéssel is meghatároztuk, mely módszerek eredményeit összehasonlítottuk. A projekt ezen részének az volt a célja, hogy a fémhab szerkezetről információkat gyüjtsünk, valamint a vizsgált fémhab próbatestek homogenitását, illetve inhomogenitását meghatározzuk.

Kulcsszavak: fémhab, területelemzés, vonalelemzés, statisztikai elemzés, modellezés.

\section{Bevezetés}

A vizsgálatunk anyaga zárt cellás alumínium hab, amelyet a Debreceni Egyetem Müszaki Kar Gépészmérnöki Tanszéke gyártott le. A fémhabunk alapanyaga F3S.20S Metal Matrix Composite Durcalan. Mit is kell tudni a fémhabokról? Ez egy viszonylag új anyag, amelynek kiváló a hővezetési tényezője, hangszigetelő képessége, illetve nagyon jó az energia elnyelő képessége.

Az általunk végzett vizsgálatokra azért van nagy szükség, mivel a fémhabok felhasználási területe rendkívül széleskörü. Az autóiparban és a biomechanikában mindennapi anyagnak tekinthető. Például a fémhabok ortopédiai alkalmazásában komoly lehetőségek rejlenek, a szivacsos csontállományhoz nagyon hasonló szerkezet a csontnövekedéshez ideális körülményeket teremt, kis sürüsége, az alapanyag jelentős teherbírása kifejezetten alkalmassá teszi a hosszú távú használatra.

Cikkünkben a fémhab struktúrájának elemzését mutatjuk be. Első lépésként a próbatestek felületeiröl (16 db próbatest) makro felvételeket készítettünk. Az elkészített képek segítségével megvizsgáltuk az anyag vonalmenti sürüségét, illetve képelemző szoftver segítségével meghatároztuk a területarányt. A vizsgálat eredményeit összehasonlítottuk és elemeztük.
Ezt követően bemutatjuk a fémhab modellezéseinek lehetőségeit, és az általunk eddig elért eredményeket, és a további célokat.

\section{Fémhab struktúrájának elemzé- se}

A következőkben a fémhab próbatestek szerkezeti felépítését (struktúráját) vizsgáltuk. Ez elengedhetetlen dolog a 3D-s modell felépítéséhez. Elsőnek a fémhab oldalairól makro felvételt készítettünk (1.ábra), majd ezeknek a képeknek felhasználásával meghatároztuk a test térfogatarányát.

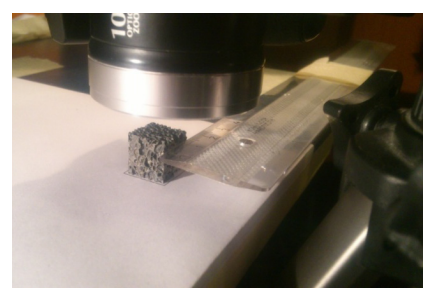

1. ábra. Makro felvételek készitésének folyamata

Az általunk használt két módszer a vonalelemzés (manuális úton) és a térfogatelemzés (képelemző szoftver segítségével).

A fémhab próbatestre jellemző térfogatarány mind a területelemzés módszeréből, mind pedig a vonalelemzés eredményeiből származtatásra kerültek. A két módszer által meghatározott mennyiség egymással egyenértékü [1]. 


\subsection{Területelemzéses vizsgálat}

$\mathrm{Az}$ általunk készített makro képeket módosítani kellett, hogy későbbiekben az elemző szoftver fel tudja dolgozni, melynek lépéseit a 2.ábra szemlélteti.
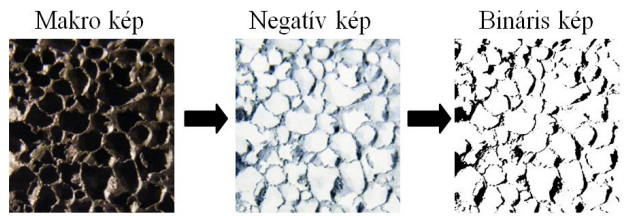

2. ábra. Makro felvételek szerkesztése, területelemzéshez

Az általunk használt képekről először negatív felvételt készítettünk, majd ezután a képet bináris képként mentettük le, amely teljes egészében csak fekete-fehér pixelekből épül fel. A képelemző szoftver úgy müködik, hogy a fekete pixelek számát elosztja az összes pixel számával, és így jön ki a százalékos területarány eloszlása az adott oldalnak.

Az [2] publikáció szerint a területelemzéses módszerrel kapott eredmények elméletileg megegyeznek a test térfogatarányával.

\subsection{Vonalelemzéses vizsgálat}

A vizsgálat során vonalelemzéssel becsültük meg a test térfogatarányát. A próbatestek oldalairól készített makro felvételeken hajtottuk végre a vizsgálatot. Az elemzés során, a képen 10 vonalat helyeztünk függőlegesen, illetve vízszintesen, egymástól egyenlő távolságra. Ezeken a vonalakon mértük azt a szakaszt, ahol anyag van a vonal mentén, majd ezeket az értékeket összeadtuk, és elosztottuk az oldalél nagyságával (3.ábra). A vonalelemzéses vizsgálat során a képeket CAD szoftver (AutoCad) segítségével méreteztük be, ezzel garantálva a pontos szakasznagyság meghatározását. Ezen vizsgálati módszer előnye a pontossága, de óriási hátránya hogy nagyon időigényes, hiszen ezt a mód- szert kézzel kell elvégezni. A fémhab próbatest egy oldalán végzett vizsgálat körülbelül 30 perc, tehát az összes próbatest öszszes oldalának kielemzése legalább 48 órát vett igénybe.

A [3] publikáció szerint a vonalelemezéses módszerrel kapott eredmények elméletileg megegyeznek a test térfogatarányával.
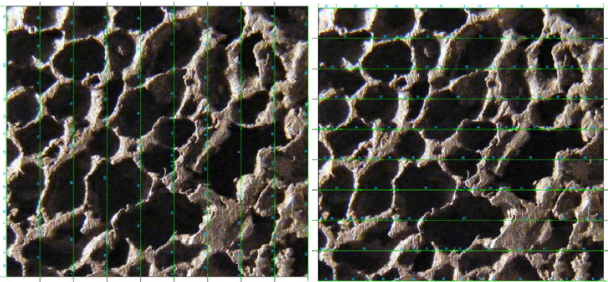

3. ábra. Vonalelemzéshez szükséges méretek meghatározása

\subsection{Vizsgálati módszerek összehason- lítása}

Abban az esetben, ha egy anyag második fázisa a levegő, akkor a térfogatarány meghatározható a test tömegéből. Ezt a tényt ellenőrzésként felhasználtuk a másik két vizsgálati módszer mellett. A vizsgálati módszerek által meghatározott értékeket a 4.ábra tartalmazza [4-5].

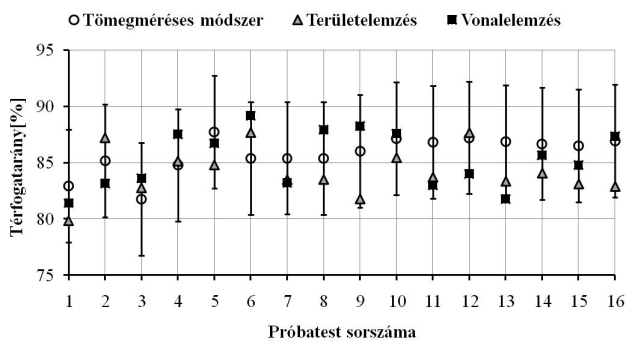

4. ábra. A vizsgálati módszerek összehasonlitása

A diagramon jól látható, hogy egyes próbatesteknél a vizsgálati módszerekkel kapott eredmények közel azonosak. Az általunk elkészített két vizsgálati módszer (vonalelemzés és térfogatelemzés) közel megegyeznek a test tömegéből meghatáro- 
zott térfogatarányra, tehát a vizsgálati eredményeink pontosnak mondhatóak. Levonható, hogy a területelemzéses módszer pontossága hasonló a vonalelemzéses módszerhez képeset, így a kiértékelés időszükséglete miatt azt célszerü választani.

\section{Fémhab modellezési lehetőségei}

A fémhab modellezésének két lehetősége van. Az egyik az, hogy statisztikai adatokból (átlagos cellaátmérő, térfogatarány, stb.) által felépítünk egy idealizált modellt, a másik lehetőség, hogy a legyártott fémhabról ipari CT felvételeket készítünk, és azt rekonstruáljuk 3D-s modellé. Mindkét eljárásnak van elönye és hátránya is. Az idealizált modell előnye, hogy néhány előre meghatározott adatból képesek vagyunk felépíteni egy modellt, de a nagy hátránya az, hogy csak megközelítőleg tudjuk szimulálni a fémhab reakcióját, hiszen ez a 3D-s modell nem teljesen egyezik meg a legyártott próbatesttel. A CT felvételnek nagy előnye, hogy ugyanazt a 3D-s geometriát tudjuk vizsgálni, mint a vizsgált fémhab. Hátrányként sajnos a 3D-s modell készítéséhez szükséges egy ipari CT berendezés, amely nagyon drága. [6]

\section{Következtetések}

A fémhab struktúrális vizsgálata során nagyon sok következtetést le tudtunk vonni a vizsgálati módszerekkel kapcsolatban. Az egyik legfőbb következtetésünk az, hogy a fémhab térfogatarányát viszonylag pontosan meg tudjuk határozni vonalelemzéssel és területelemzéssel egyaránt. Továbbá fontos azt kijelenteni, hogy a területelemzéses módszer is van olyan pontos, mint a vonalelemzéses, tehát nem muszáj annyi időt tölteni a vonalelemzéssel, hisz a másik módszer is van legalább olyan pontos.

A jövőbeli terveink között szerepel az, hogy a CT felvételek által meghatározott térfogatarányokat összehasonlítsuk az eddigi vizsgálati eredményekkel.

\section{Szakirodalmi hivatkozások}

[1] Underwood, E.E., Quantitative Stereology, Addison-Wesley Publishing Company, 1970.

[2] Saltykov, S.A.,Stereometrische Metallographie. VEB Verlag, Leipzig, 1974.

[3] Hilliard, J.E., Measurement of Volume in Volume. Quantitative Microscopy, McGrawHill, New York, 1968.

[4] Varga, T. A., Mankovits, T., Budai, I., Balogh, G., Gábora, A., Kozma, I., Manó, S., Kocsis I., Structural analysis and its statistical evaluation of closed-cell metal foam, Proceedings of $2^{\text {st }}$ International Scientific Conference on Advances in Mechanical Engineering, Debrecen, Hungary, 10 October 2014. 178-185.

[5] Mankovits, T., Budai, I., Balogh, G., Gábora, A., Kozma, I., Varga, T. A., Manó, S., Kocsis I., Structural analysis and its statistical evaluation of closed-cell metal foam, International Review of Applied Sciences and Engineering, 5(2), 2014. 135-143.

[6] Mankovits, T., Budai, I., Balogh, G., Gábora, A., Kozma, I., Varga, T. A., Manó, S., Kocsis I., Tóth, L., Structural modeling of closedcell metal foam, Proceedings of $2^{\text {st }}$ International Scientific Conference on Advances in Mechanical Engineering, Debrecen, Hungary, 10 October 2014. 70-74. 